\title{
RAZVOJ ZDRAVSTVENO ORIJENTISANE FIZIČKE KULTURE U RUSKIM ŠKOLAMA (KRAJ XIX VIJEKA - OSAMDESETE GODINE XX VIJEKA)
}

\author{
Vladimir Irhin ${ }^{1}$ i Irina Irhina ${ }^{1}$ \\ ${ }^{1}$ Državni nacionalni istraživački Institut "BelSU”, Belgorod, Rusija
}

\section{SAŽETAK}

Ovaj rad se bavi nastankom ideja o očuvanju, poboljšanju i razvijanju zdravlja kod školske djece u Rusiji, putem fizičkog vježbanja u periodu od kraja XIX vijeka do 80-ih godina XX vijeka. Na početku XX vijeka, teorija fizičkog vježbanja u Rusiji se, između ostalog, kretala u pravcu naučnog istraživanja poboljšanja zdravlja školske djece preko fizičke kulture. Krajem XIX vijeka, u ruskoj teoriji fizičke kulture već su postojala dva istaknuta, nezavisna i donekle suprotstavljena pristupa - obrazovni $\mathrm{i}$ zdravstveni. Na početku XX vijeka, zdravstveni i obrazovni ciljevi fizičkog obrazovanja smatrani su jednakim i obaveznim. U periodu prije revolucije, u zdravstveno orijentisanom razvoju fizičke kulture u ruskim školama, čas fizičkog je bio dio obrazovnog sadržaja: kao obavezan predmet u višim školama. Cilj da se podiže jedna zdrava generacija doveo je do stvaranja inovativnih škola u prvim godinama sovjetske vlade. Vojničko-fizička obuka školske djece bila je jedna od ključnih tačaka obrazovnog procesa za vrijeme Drugog svjetskog rata. U posljeratnom period, naučnici su usmjerili svoju pažnju na proučavanje posljedica rata. Krajem 80-ih godina XX vijeka, naglo je porastao broj naučnih i eksperimentalnih radova o mjerama za poboljšanje zdravlja učenika. To je dovelo do pojave i daljeg napredovanja razvoja fizičkog obrazovanja i zaštite zdravlja učenika.

Ključne riječi: zdravstveno orijentisana kultura, škola, Rusija, istorija.

\section{UVOD}

Šezdesetih godina XIX vijeka, krajnje zaoštrene društvene kontradiktornosti odredile su veću javnu aktivnost u Rusiji. Došlo je do skoka moralnih vrijednosti među predstavnicima fizičke kulture koji su zastupali humanistički pristup u Rusiji. Čovjekova ličnost i njegovo zdravlje postali su važni faktori. Autoritativna, pragmatična fizička kultura, fizičko kažnjavanje oštro su kritikovani u naučnim studijama i praksi progresivnih mislilaca tog vremena (Аементьев, 1892; Гориневский, 1900; Покровский, 1893; itd.). Tvrdilo se da je loše fizičko zdravlje ruske djece posljedica nedostatka osmišljenog fizičkog vježbanja. Pojavila se potreba za naučnim temeljima sistema fizičkog vježbanja u školama. Eminentni stručnjaci tog doba naglašavali su međusobnu povezanost i zavisnost fizičkog razvoja i mentalne aktivnosti. Takođe su pridavali veliku važnost promovisanju zdravlja djece putem gimnastike, fizičkog rada i higijene. Isto tako, humanisti su bili protivnici dominantne vojničke gimnastike i metoda prinude u fizičkom vježbanju.
Zdravstveno - orijentisan pravac razvoja ruske teorije i prakse opšteg školskog fizičkog vježbanja sve više je dobijao na snazi.

\section{METOD}

Teoretska analiza iz pedagoških radova stručnjaka iz pomenutog perioda, komparativna analiza konkretizovana u komparativno-istorijskom i komparativnologičkom metodu, induktivno-deduktivni metod, princip naučne objektivnosti i pouzdane činjenice daju adekvatno tumačenje relevantnih pedagoških ideja.

\section{REZULTATI I DISKUSIJA}

Teoretsko proučavanje aspekata fizičkog vježbanja

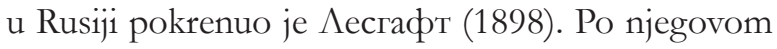
mišljenju, opšti cilj odgoja bio je "harmoničan i cjelokupan razvoj aktivnosti čovekovog tijela". Glavni pravac i uslov postizanja tog cilja je fizička kultura, za koju je P. F. Lesgaft smatrao da predstav- 
lja ne samo vježbanje mišića, već i volje i formiranje moralnih odnosa. Na osnovu psihofizičke teorije monizma, P. F. Lesgaft je izradio sistem fizičkog obrazovanja koji je predstavljao neraskidivu vezu između učeničkog morala i fizičkog razvoja. Prema $\Lambda$ есгафт (Ibid), fizičko vježbanje, kao smisaona aktivnost, bilo je sastavni element psihofizičkog procesa. U fizičkom i moralnom razvoju djeteta, presudni značaj bio je u odgoju koji treba da ima u vidu individualne razlike među djecom. P. F. Lesgaft je učinio jedan od prvih pokušaja da utvrdi psihofizičke specifičnosti učenika. U doktrini Lesgafta (Ibid) o “idealnoj osobi” mnogo pažnje je posvećeno karakteristikama tipova škole, dobijenih na osnovu dugogodišnjeg istraživanja fizičkog stanja učenika, teorijskog koncepta i praktične potvrde eksperimentalnih metoda. Glavna ideja usađena u P. F. Lesgaftova naučna zapažanja i njihovo teoretsko objašnjenje bila je da tip djeteta direktno zavisi od intelektualnog i moralnog razvoja. Autorova zasluga je u njegovom nastojanju da ispita tipove djece na osnovu antropoloških položaja. Međutim, primjena samo jednog naučnog metoda - posmatranja, odsustvo određenih osobina datog tipa i precizno izraženih kriterijuma njihovog utvrđivanja - nisu omogućili da se u potpunosti shvati njegov zanimljiv i praktičan koncept. Godine 1896. P. F. Lesgaft je osnovao Institut za proučavanje ljudi, koji je trebao (prvi u svijetu) da se bavi složenim problemima ljudi. Svi ovi faktori imali su polaznu vrijednost za nastanak ruske teorije i prakse fizičkog vježbanja, usmjerene ka odgajanju zdrave osobe.

Tokom perioda izučavanja ideje o brizi za zdravlje učenika, stvaranje zdrave sredine u kojoj đaci uče i žive uvedeno je u praksu "novih škola": Levitskaje u Carskom Selu (1900), Petrove gimnazije u Novočerkasku (1906) i Jakovljevoj u Galicinu kod Moskve (1910). "Nove škole" su, po pravilu, obično koristile prirodne faktore (čist vazduh, šume, rijeke) da se popravi zdravlje djece. Na primjer, u Levitskaja školi mnogo pažnje se posvećivalo fizičkom vježbanju i igrama na otvorenom: klizanju, hokeju, skijanju, fudbalu, tenisu, lapti. Dvadesetominutne vježbe radile su se napolju, između časova, često uz muziku. Đački dan počinjao bi jutarnjim trčanjem (bez obzira na vremenske prilike) i pljuskanjem hladnom vodom. Tri puta nedjeljno održavali su se časovi drilovanja, a drugim danima časovi sporta: gimnastika, trčanje, vježbe na paralelnom razboju. Za početnike i slabiju djecu, program fizičkog vježbanja bio je individualizovan (Ирхин, 2002).

Na početku XX vijeka, teorija fizičkog vježbanja u Rusiji se, između ostalog, kretala u pravcu naučnog istraživanja poboljšanja zdravlja školske djece preko fizičke kulture. Istraživanja koja su sproveli zdravst- veni radnici od 70-ih do 90-ih godina XIX vijeka, pokazala su ne samo nizak stepen fizičkog razvoja većine učenika, već su utvrdila i negativan uticaj obrazovnog procesa na somatsko i mentalno zdravlje učenika. Pedagoška zajednica insistirala je na uvođenju fizičkog vježbanja u nastavni plan i program, kao obaveznog predmeta, kao i izbacivanje dominantne drilovane gimnastike. U maju, u Teniševski eksperimentalnim školama, Mogiljanski ženskoj gimnaziji, Medvednikovoj gimnaziji, Stojuninoj ženskoj klasičnoj školi, osmogodišnjoj trgovačkoj školi u Lesnoju (Sankt Peterburg), mnogo pažnje posvećivalo se sadržaju fizičke kulture, metodama, oblicima i obaveznim, svakodnevnim časovima fizičkog. Igre na otvorenom, pješačenje, ekskurzije, elementi individualnih sportova koristili su se kao sredstvo fizičkog vježbanja. Njihova nova primjena predstavljala je kontrast zvaničnoj pedagogiji koja je smatrala da su dva do četiri polučasovna odmora nedjeljno dovoljna za fizički razvoj djece u školi.

Praksu u naprednim školama podržavala su i teoretska istraživanja u oblasti fizičke kulture. Krajem XIX vijeka, u ruskoj teoriji fizičke kulture već su postojala dva istaknuta ali nezavisna, donekle suprotstavljena pristupa - obrazovni i zdravstveni. Osnivač obrazovnog pristupa P. F. Lesgaft, utvrdio je da je cilj fizičkog obrazovanja čovjeka postizanje inteligentnog upravljanja motoročkim aktivnostima.

Osnivač zdravstvenog (zdravstveno - orijentisanog) pristupa E. A. Pokrovski i njegovi sljedbenici (Аеменьев, 1892; Филитис, 1916; ГерА, 1912; i drugi) smatrali su da je cilj fizičkog obrazovanja u postizanju boljeg zdravlja. Ispitivanja koja su vršili školski ljekari krajem XIX vijeka, omogućila su da se otkrije šta je razlog lošeg zdravlja učenika. U vezi s tim, Гориневский (1951) i njegovi saradnici smatrali su da je važno da se vježbanje koristi radi oslobađanja od mentalne napetosti.

Prema tome, specifičnosti razvoja sredine, teorija i praksa fizičke kulture, formiranje školske higijene i druge nauke povezane sa fizičkim vežbanjem, zahtijevali su, kao prioritet, razvijanje Lesgaftovog sistema fizičkog obrazovanja i sređivanje zdravstveno - orijentisanih problema.

Početkom XX vijeka, zdravstveni i obrazovni zadaci fizičkog obrazovanja smatrani su jednako važnim i obaveznim, a to je predstavljalo suštinsko ostvarenje ruske pedagoške misli.

U periodu između dvije buržoasko-demokratske revolucije u Rusiji (1905. i 1917) došlo je do oscilacija u istraživanjima u oblasti fizičke kulture kod učenika. Бекарюков-a (1914), Гориневский-eva 
(1913, 1916) і Игнатьев-а (1912), smatrani su za najvažnije naučne radnike ovog perioda.

Lesgaftovu ideju o ujedinjavanju raznih obrazovnih aspekata (uma, duha i tijela) razvio je V. V. Gorinevski. Ovaj naučnik je formulisao tri grupe zadataka koje ima fizička kultura: očuvanje i poboljšanje zdravlja; opšti razvoj djeteta i formiranje čovjekovih moralnih kvaliteta. Značajan doprinos Gorinevskog je u tome što je dokazao potrebu za naučnom osnovom sistema fizičke kulture u školama. Rezimirajući predrevolucionarni period razvoja zdravstveno - orijentisane fizičke kulture u ruskim školama, treba primijetiti da je čas fizičkog bio ubačen u obrazovni sadržaj kao obavezan predmet u višim školama. Istovremeno se smatrao i načinom za poboljšanje zdravlja djece.

Poslije Oktobarske revolucije (1917), u Rusiji pažnja stručnjaka bila je usmjerena na negativne i po zdravlje učenika štetne fenomene, te proučavanje društvenih i pedagoških uslova koji su izazivali te procese.

U ovom period, P. F. Kapterev je naučno dokazao da moralni razvoj djeteta počiva na osnovu povezane "aktivnosti mozga, nerava, mišića, krvi". Po njegovom mišljenju, jedini način da se postignu pozitivni rezultati u odgajanju zdrave osobe jeste da se upozna sa djetetovom fiziologijom i psihologijom (Каптерев, 1914). Do sredine 20 -ih godina prošlog vijeka, među naučnicima koji su se bavili pitanjem školske higijene, školskih sanitarija i fizičkog vježbanja (Гориневский, 1927; Иорданский, 1927), preovladavalo je stanovište o potrebi za integrisanjem ovih naučnih pristupa i njihovim povezivanjem pod zajedničkim nazivom "fizička kultura". Fizičku kulturu su dovoljno široko interpretirali zdravstveni radnici, a trebala je da pokriva sve aspekte školskog života:

[...] spoljašnje uslove oko škole, đačku individualnu i kolektivnu higijenu tokom učenja i svakodnevnog života, brigu za školske obroke, programe suzbijanja bolesti u školi, organizovanje zdravstvene kontrole i brige za školu, higijenu nastavnika, rad škole na popularizaciji zdravog života, sanitarno-higijenske kontrole za djecu izvan škole (Иорданский, 1927, str. 264).

Stručnjaci iz 20-ih godina XX vijeka, shvatili su da problem odgajanja zdrave generacije može da riješi samo "zdrav, snažan i veseo nastavnik," pošto "njegov nervni sklop i zdravstveno stanje direktno utiču na njegova predavanja. Narušeno će ga oslabiti i dati slabije rezultate u njegovom radu" (Ibid, str. 279). Prema tome, briga o u zdravlju nastavnika, mjere za poboljšanje njihovog zdravlja, samoobrazovanje u oblasti fizičke kulture i lične higijene, bili su u žiži interesovanja stručnjaka u toj oblasti. U prvom planu su bili problemi uključivanja nastavnika u zdrav način života, organizovanje rada nastavnika na naučnoj osnovi i stvaranje zdravih uslova rada za tehničko osoblje.

Namjera pedagoške teorije i napredne nastavničke prakse da kod generacije koja raste razvije samostalnost i kreativnost, uslove za fizički i moralno zdravu osobu, graditelje socijalističkog društva, dovela je do stvaranja inovativnih škola već u prvim godinama sovjetske vlade. Proces poboljšanja zdravlja i obrazovne aktivnosti primjenjivao se u praksi ondašnjih škola. Organizovanje ljetnjih škola omogućavao је "Положение о единой трудовой школе" [Pravilnik o zajedničkoj radničkoj školi] (1918) i posebni "Pravilnik o ljetnjoj školi” koji je usvojio Narkompros (Министерство образования, 1920). Zadaci ovih škola podrazumijevali su i promovisanje zdravlja djece, njihovog sportsko-zdravstvenog obrazovanja i organizovanje korisnog slobodnog vremena.

Određeni su različiti tipovi i fleksibilni oblici organizovanja ljetnjih škola: učionice sa otvorenim prozorima; škola ili internat na otvorenom, sa zadatkom da ujedine potrebe dječjeg organizma i učenje; škola u šumi u kojoj su preovladavali sportskozdravstveni zadaci u odnosu na pedagoške i obrazovne; dječija ljetnja kolonija u kojoj se realizovao princip rada i upoznavanje prirode, a takođe se poboljšavalo fizičko zdravlje djece i stvarala atmosfera koja najviše odgovara njihovom mentalitetu; dječije ljetnje igralište (za buduće generacije); ljetnja seoska škola u kojoj se sprovodila ideja poboljšanja zdravlja djece iz grada u uslovima seoske sredine; eksperimentalna škola u vidu periodičnih sastanaka djece na raspustu (ponekad vikendom). Nastavnici u ljetnjim školama nailazili su na brojne teškoće u svom radu, materijalne i tehničke (nedostatak sportske opreme i sala), metodičke (nedovoljan nivo obrazovanja nastavnika) i organizacione (nehumano radno vrijeme nastavnika, prigovaranje). Svi ovi problemi znatno su umanjivali njihovu radnu produktivnost i proizveli nerealan pokušaj da se ljetnja škola označi kao nezavisna, odvojena od redovne škole. U isto vrijeme, iskustvo sa korisnim sportskozdravstvenim javnim aktivnostima u ovim obrazovnim institucijama je danas veoma prisutno: naročito iskustvo vezano za organizovanje neprekidne nastave i obrazovnog procesa koji obuhvata fizičku aktivnost.

Eksperimentalne institucije iz 20-ih i 30-ih godina prošlog vijeka dale su značajan doprinos konceptu očuvanja i razvijanja zdravlja kod školske djece u Rusiji. U eksperimentalnom centru pod vođstvom S. T. Šatskog, od velikog značaja bila je povezanost intelektualnog i fizičkog obrazovanja. Osim posebnih fizičkih vježbi, S. T. Šatski je dosta pažnje posvećivao uvođenju zdravih uslova života i znanja o fizičkoj 
kulturi u školski život na selu. Mora se naglasiti da je svaka eksperimentalna škola imala sopstveni istraživački cilj. Tako je Kraskovo-Malahovski eksperimentalni centar radio na predmetu "Racionalan prikaz fizičkog vježbanja u gimnazijama". Sportske aktivnosti su se izvodile ne samo u obrazovnom procesu, već i u okviru mentorskog rada, zasnovanog na učeničkom parlamentu. Posebna pažnja posvećivala se borbi protiv pušenja kod starijih učenika. Zbog toga se u školskom izvještaju za 1920/21. godinu, kaže da je „procenat učenika koji puše u 6. i 7. razredu bio strašno mali i da među 40-50 osoba - nije bilo pušača; u 8. razredu - na 50 osoba - 5-6 pušača, u 9. razredu (stariji) - na 40 osoba - 1 pušač” (Иванов, 1969).

V. P. Kaščenko je ustanovio dovoljno efikasan obrazovni sistem, usmjeren na očuvanje, promovisanje i razvijanje zdravlja djece zahvaljujući svom dugogodišnjem operativnom iskustvu u medicinskopedagoškoj stanici Narkompros RSFRS (Кащенко, 1922). Cilj ovog sistema bio je da se izbjegne fizički i psihološki premor učenika, da se u što većoj mjeri iskoriste i razviju njegove sklonosti i sposobnosti, kao i sprovođenje mjera za sprečavanje negativnih aspekata u razvoju ličnosti. Ovakav pristup zahtijevao je sveobuhvatnu studiju, zasnovanu na fundamentalnim dostignućima fiziologije i psihologije, uz saradnju ljekara i nastavnika. U srži obrazovne aktivnosti bio je eksperimentalno-kreativan, aktivan motorički proces. Uzimale su se u obzir godine djeteta i njegove psihofizičke osobenosti.

V. P. Kaščenka nije interesovao kvantitet, već kvalitet znanja školske djece, razvoj njihove individualnosti, stepen neposrednog angažovanja u životu.

Od presudnog značaja za postizanje ovih ciljeva bila je kreativnost djece i nastavnika. Djeca su dosta učila u prirodi za vrijeme pješačenja i izleta, posmatrajući zalazak sunca, ljepotu ljetnje noći, posmatrajući život životinja i biljaka. Svi ovi utisci imali su svoj izraz u dječjim crtežima. Ti izlasci i tzv. "vazdušni izleti” - 5 versta (1 verst iznosi oko $1 \mathrm{~km}$ ) pješačenja organizovanog nedjeljom - predstavljali su i oblike aktivnog odmora. Poslije dugog pješačenja, aktivnost djece bila je ograničena i zamjenjivana je raznim vrstama "nijemih" igara. "Olimpijske igre", sa svojim sportskim disciplinama, nadmetanjima i takmičenjima u književnosti, likovnom, muzičkom i drugim vrstama kreativnog izražavanja, bile su složena forma rada u školama sanatorijumima. Tokom "Olimpijskih igara", sastajali su se prijašnji učenici sa sadašnjim, održavale su se izložbe učeničkih likovnih radova, pozorišne predstave. Baveći se duhovnim interesovanjima učenici ne samo da su bili odvraćani od opstruktivnog raspoloženja, izbjegavajući inerciju, nego su i sticali znanja o karakteristikama ličnosti, formirajući sopstveni “pojam o sebi”. Formiranje tog pojma olakšavala je atmosfera duhovnosti, emotivnog zadovoljstva i povjerenja. Za zaposlene u školi - sanatorijumu, birani su stručnjaci različitih profila, sa specijalnim obrazovanjem, kako bi dijete bilo okruženo ljudima koji bi se dopunjavali u pogledu temperamenta, afiniteta i sposobnosti i tako stvarali okruženje pogodno za razvoj učenika.

Odmor od rada, zabava i raspored učenja imali su blagotvorno dejstvo na zdravlje djece. Mada se svakodnevni raspored pravio zajednički (na sastanku ljekarsko - pedagoškog osoblja), realizovanje i kontrolisanje njegovog primjenjivanja bili su dio mentorovih zaduženja. Da bi izvršio sve ove obaveze, mentor je morao da poznaje dječju pedagogiju, psihologiju, fiziologiju, lične osobine, ali i da ima izvjesne osobine snažne volje i poslovnosti jednog profesionalca dobrog zdravlja. Sistem raspodjele rada između nastavnika i mentora, organizovanje u mikrogrupe (10-12 djece), redovne smjene tokom dana i odmor poslije noćne smjene, imali su za cilj očuvanje zdravlja mentora.

Trenutno se Kaščenkovo pedagoško nasleđe nedovoljno proučava. Ideje koje je V. P. Kaščenko predstavio u sistemu poboljšanja zdravlja djece, mogu da se na kreativan način iskoriste ne samo u specijalnim medicinsko-pedagoškim institucijama, već i pri organizovanju sportskih aktivnosti u srednjim školama u Rusiji i drugim državama.

Teorijske i praktične aktivnosti sovjetskih pedagoga i psihologa, fiziologa i zdravstvenih radnika 20-ih i 30-ih godina prošlog vijeka (Бехтерев, 1928; БАонский, 1930; Гориневский, 1927; ИорАанский, 1927; Кащенко, 1922; i drugi) nedvosmisleno su pokazale da je okrenutost ka očuvanju i maksimalnom razvoju zdravlja učenika centar i suština fizičke kulture u školi. Doprinos istraživačkih aktivnosti naučnika iz tog perioda ogleda se nastajanju suštinski novog obrazovnog sistema i vježbanja učenika na temeljima naučno-materijalističke teorije. Međutim, dalji razvoj zdravstveno - orijentisanog fizičkog vježbanja u ruskoj školi sprečili su kult Staljinove ličnosti, destruktivnost domaće pedologije, genetike, zatvaranje eksperimentalnih školskih centara. Dugo godina su očuvanje učeničkog fizičkog i mentalnog statusa i stvaranje njegove kulture zdravlja ležali po strani u istraživanjima obrazovnog procesa. Broj istraživanja koja su se bavila gore pomenutim problemima naglo je opao od druge polovine 30-ih do kraja 40-ih godina prošlog vijeka. Izuzetak je bio naučni rad Берман і Мильмана (1935) i njihovih sljedbenika: ААрианова (1941), Черток, Мильман і Заблудовский (1940), te 
Нимен $(1941,1945)$ koji su se bavili sportskozdravstvenim obrazovanjem djece u osnovnoj školi.

Drugi svjetski rat je situaciju sa životom i zdravstvenom zaštitom djece učinio još gorom. Vojničkofizičko vježbanje među školskom djecom bilo je jedno od centralnih mjesta u obrazovnom procesu. Počivalo je na specijalnom kursu predvojničke obuke starijih učenika i sistema vanškolskih aktivnosti: sportske i odbrambene studijske grupe i sekcije, sveruske vojničke vježbe ("Napad u neprijateljskoj pozadini", 1942; “Za odbranu”, 1943; “Za napad”, 1944). Obrazovni planovi obuhvatali su sportska nadmetanja, ukrštanja, kontrolisanje đačke vojničke i fizičke obuke. Na primjer, u školama u regionu Altaja u školskoj 1941/42. godini bilo je 29.000 školske dece u studijskim grupama za odbranu od vazdušnih i hemijskih napada, oko 1.000 u streljačkoj sekciji, 1.500 u sportskim (Равкин, 1988).

Tokom 40-ih godina naučni radovi Семашко (1947), Советов (1956), Цейтлин (1963) i drugih bavili su se fiziološkim, zdravstvenim i pedagoškim aspektima fizičkog obrazovanja, zdravstvenim problemima djece i očuvanju i poboljšanju zdravlja tinejdžera. Godine 1944. Institut za istraživanje zdravlja u školama pri Pedagoškoj akademiji RSFSR (sada Institut za starosnu fiziologiju) osnovan je na inicijativu i pod vođstvom N. A. Semaška. Od tada se sprovode složena interdisciplinarna teoretska i primijenjena istraživanja u oblasti starosne fiziologije i morfologije, zdravlja u školama i fizičkog vježbanja učenika srednjih škola.

U posljeratnom period, naučnici su usmjerili pažnju na proučavanje posljedica rata. Prema rezultatima Državne sanitarne inspekcije USSR-a, izvršene u školskoj 1945/46. godini, došlo je do zastoja u razvoju školske djece po antropometrijskim pokazateljima u poređenju sa sličnim pokazateljima u periodu od 1938. do 1940. godine.

Četrdesetih i pedesetih godina primećene su pozitivne promjene u razvoju sedmogodišnjeg obrazovanja. Međutim, nedostatak stručnog sportskog osoblja, sportske opreme i sala te slaba zdravstvena vrijednost obrazovnog procesa, loše su uticali na zdravlje nastavnika i učenika.

U periodu od kraja 40-ih do sredine 50 -ih godina o problemu poboljšanja zdravlja školske djece putem fizičkog vježbanja Vlada je sistematski raspravljala. U decembru 1948. godine, Narkompros RSFSR-a donio je "Zakon o poboljšanju fizičkog vježbanja u školama" koji je definisao osnovne pravce rada u toj oblasti. Godine 1956, usvojen je zakon ministarstva prosvete RSFSR o obaveznoj jutarnjoj gimnastici u školama i djelimično izmijenjen standard "Budite spremni za rad i odbranu”. Ipak, fizičko vježbanje učenika os- talo je najudaljenija sfera u obrazovnoj aktivnosti u školama (Равкин, 1988).

Krajem 50-ih i početkom 60-ih godina prošlog vijeka, pitanje očuvanja i razvoja zdravlja djece postavljeno je u centar pažnje naučnih radnika. Bilo je određeno društvenim procesima u državi: s jedne strane došlo je do postepenog, bolnog poricanja prethodne taktike prisile u obrazovanju, a s druge strane su oživjeli humanistički trendovi koji su priznavali čovjekove potrebe. Uočeni su društveni, ekonomski i moralni konflikti u društvu, porast aktivnosti kod djece i tinejdžera koje su štetile njihovom zdravlju. U tom periodu naučnici (Антропова, 1968; Громбах, 1959) su se okrenuli neophodnom usavršavanju pedagoške sredine u školama. Советов (1956) i Мильман (1966) isticali su značaj popularizacije medicinsko-zdravstvenog znanja među školskom decom. Tokom 60-ih godina prošlog vijeka bilo je neophodno da se stvori naučna osnova za fizičko vežbanje školske dece (Кузнецова, 1998; Аях, Кофман і Мейксон, 1996).

Tokom 70-ih i 80-ih godina prošlog vijeka došlo je naglog porasta broja istraživanja u oblasti fizičkog obrazovanja i zdravstvene zaštite učenika. Problemi adaptacije djece i tinejdžera na obrazovne i fizičke napore bili su predmet rada Антропова (1968). Rad Колесов-а і Хрипкова (1982) bavi se problemom puberteta i seksualnog obrazovanja, preventivnih mjera za sprečavanje štetnih navika.

Od 1985. godine, stručnjaci su počeli da istražuju uticaj kompjutera na organizam učenika kako bi dokazali tehnologije očuvanja zdravlja pri upotrebi PC (zajedno sa sferom fizičkog obrazovanja) u obrazovnom procesu učenika (L. A. Leonova). Godine 1986. radnici Naučnog instituta za fiziologiju dece i tinejdžera pri Pedagoškoj akademiji SSSR-a sačinili su "Složeni program za medicinsko-zdravstveno obrazovanje učenika u srednjim školama". A zatim je izrađen obrazovni i metodički kompleks za zdravstveno obrazovanje školske djece: metodičke preporuke za nastavnike u srednjim školama.

Tako se do kraja 80-ih godina nakupilo mnoštvo značajnih naučnih i eksperimentalnih radova na temu izrade školskog plana i programa, nastavnih metoda koje bi odgovarale funkcionalnim mogućnostima učenika i fizičkog obrazovanja u cilju pokretanja mjera za poboljšanje zdravlja učenika, definisanja prihvatljive granice intelektualnog i fizičkog naprezanja.

\section{ZAKLJUČAK}

Analiza specifičnosti razvijanja zdravstveno - orijentisanog fizičkog vježbanja u Rusiji iz predrevolu- 
cionarnog perioda pokazuje da su antropološki, humanistički i zdravstveni pristup njegovanju i organizovanju fizičkog obrazovanja u školama utvrđeni krajem XIX vijeka su nastavili da se razvijaju. Ovi pristupi su osnaženi naučnim dostignućima pedagoške psihologije (Нечаев, 1899; Аазурский, 1913; Рубиншттейн, 1920).

Došlo je do integrisanja obrazovnog i zdravstvenog aspekta teorije fizičke kulture (Аесгафт, 1988; Покровский, 1893). Istovremeno, nije došlo do integrisanja ovih teorijskih pristupa u granicama naučne i pedagoške teorije usmjerene ka poboljšanju zdravlja integralnog školskog obrazovnog sistema. Naučni radovi bili su daleko od prave školske prakse i realizovani u elitnim obrazovnim institucijama.

Tokom 20-ih i 30-ih godina prošlog vijeka, u pedološkim istraživanjima pojavio se trend zasnovan na antropološkom pristupu učenju i vaspitavanju (Басов, 1931; Блонский, 1930; Выготский, 1931). U isto vrijeme je stanovište o neophodnosti udruživanja ovih naučnih pristupa pod zajedničkim imenom "fizičko obrazovanje" dominiralo među onima koji su se bavili problemom školskog zdravlja, higijene i fizičkog vježbanja. Međutim, nedostatak naučne metodologije nije dozvoljavao da dođe do sličnog integrisanja.

U eksperimentalnim školama 20-ih i 30-ih godina prošlog vijeka akumuliralo se pozitivno iskustvo o zdravstvenom i fizičkom obrazovanju predmeta pedagoškog procesa, sprečavanju bolesti i devijacijama u razvoju djece. Kult Staljinove ličnosti i dominacija komandno-administrativnog državnog sistema ozbiljno su narušili napredovanje teorije i prakse u oblasti zdravstveno - korisnog fizičkog obrazovanja u sovjetskim školama. U tom period zatvoren je put naučnog istraživanja u pedologiji i genetici; smanjen je broj genetskih eksperimentalnih školskih centara, a progresivne antropološko-humanističke ideje bile su osuđene na zaborav.

Društveno "otopljenje" krajem 50-ih i sredinom 60-ih godina, kao i dalje oživljavanje humanističkih tendencija, podstaklo je realizaciju očuvanja zdravlja školske djece putem fizičkog vježbanja. U periodu od kraja 50-ih do 80-ih godina XX vijeka, postajao je trend kvantitativne ekspanzije istraživanja fizičkog i zdravstvenog obrazovanja i zdravstvene zaštite učenika (Антропова, 1985; Громбах, 1988; Кузнецова, 1998; Шарипова, 1990).

Zajednička karakteristika teorijskog i praktičnog istraživanja iz tog perioda bila je orijentisanost ka obrazovnom procesu sa zdravstvenim modelom, prvenstveno usmerenim na zaštitu od bolesti, ali ne i na unapređivanje zdravlja pojedinca. Prema tome, ovo nije moglo da riješi problem obrazovanja zdrave osobe u punoj mjeri. Istovremeno su brojni teoretski i eksperimentalni radovi iz XX vijeka u oblasti ruskog fizičkog obrazovanja sa ciljem poboljšanja zdravlja postavili temelje ruske teorije pedagogije zdravlja i nastanka ideja o savremenom zdravstveno korisnom vježbanju u srednjim školama 90-ih godina prošlog vijeka.

\section{LITERATURA}

ААрианова, А. Е. (1941). Воспитание санитарногигиенических навыков у учащихся I класса [Vaspitavanje sanitarno-higijenskih navika među učenicima prvog razreda]. Москва: Гос. научно-исследов. ин-т школ НКПроса РСФСР.

Антропова, М. В. (1968). Работоспособность учамихся и её динамика в прочессе учебной и mрудовой деятельности [Radna sposobnost učenika i njena dinamika u porcesu učenja i rada]. Москва: [n.p.].

Антропова, М. В. (1985). Физиолого-гигиенические рекомендауии по нормализачии учебной нагрузки учащихся 7-10 классов [Fiziološko-higijenske proporuke o normalizaciji školskih opterećenja učenika 7-10 razreda]. Москва: АПН СССР.

Басов, В. Н. (1931). Общие основы педологии [Opšti principi pedologije] (2nd ed.). Москва: ГИЗ.

Бекарюков, А. А. (1914). Основные начала шкальной гигиеньъ [Osnovni principi školske higijene]. Москва: nema izdavača.

Бехтерев, В. М. (1928). Мозг и его деятельность [Mozak i njegova aktivnost]. Москва: [n.p.]. Берман, Ф. Ю. и Мильман, И. И. (1935). Материальи для ведения уроков по охране здоровья (санчасов) в I и II классах начальной шкальв: Сборник методических разработок [Materijali za provođenje časova o zdravlju (sanitrani časovi) u I i II razredu osnovne škole: Zbornik metodoloških razrada]. Москва: Ин-т сан. Культуры.

БАонский, П. П. (1930). ПеАология [Pedologija]. Москва: Работник просвещения.

Черток, О. И., Мильман, И. И. и Заблудовский, П. Е. (1940). Предупреждение заразныхх болезней в школе: Сборник методических материалов по camnросветработе [Prevencija zaraznih bolesti u školi: Zbornik metodičkih materijala za sanitarno obrazovni rad]. Москва: Центр. Ин-т сан. просв. ХКЗАрава СССР.

Аементьев, Е. М. (1892). Гимнастика и игры [Gimnastika i igre]. Москва: [n.p.].

Филитис, Н. С. (1916). Подвижньге ирры детских садов [Igre na otvorenom u dječijim vrtićima]. Москва: [n.p.]. 
ГерА, И. Я. (1912). Сборник игр и полезнъцх занятий для всех возрастов [Zbornik igara i korisnih zanimanja za sve uzraste]. Ст. Петербург: СПБ.

Гориневский, В. В. (1900). О закаливании человеческого организма, как средстве воспитания [O kaljenju ljudskog tijela kao sredstvu vaspitanja]. Москва: [n.p.].

Гориневский, В. В. (1913). Физическое образование [Fizičko vaspitanje]. Ст. Петербург: СПБ.

Гориневский, В. В. (1916). Физические упражнения, соответствуюшие данному возрасту [Fizičke vježbe koje odgovaraju uzrastu]. Ст. Петербург: СПБ.

Гориневский, В. В. (1927). Культура mела [Kultura tijela]. Москва: [n.p.].

Гориневский, В. В. (1951). Избранныле трудъг [Odabrani radovi]. Москва: [n.p.].

Громбах, С. М. (1959). Гигиена учебных занятий в школе [Časovi higijene u školi]. Москва:

Медицина.

Громбах, С. М. (1988). Школа и психическое здоровье yчашихся [Škola i mentalno zdravlje učenika]. Москва: Медицина.

Игнатьев, В. Е. (1912). Физическое развитие детей в связи с гигиеной [Fizički tazvoj djece u odnosu na higijenu]. Москва: [n.p.].

Иорданский, Н. И. (1927). Школоведение: Руководство для массового уиителя [Školske uprave: Smjernice učiteljima]. Москва:

Просвещение.

Ирхин, В. Н. (2002). Теория и практика отечественной школь здоровья [Teоrija i praksa nacionalne škole zdravlja]. Барнаул: Азбука.

Иванов, А. Г. (1969). Опьтнно-показательныге школьг Наркомпроса РСФСР (1918-1937) [Eksperimentalno-demonstracione škole Narkomprosa RSF-

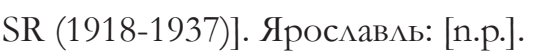

Кашенко, В. П. (1922). Аефективныле дети в школе [Hendikepirana djeca u školama]. Москва: [n.p.].

Каптерев, П. Ф. (1914). Новая русская педагогика, ёе главнейшие идеи, направления и деятели [Nova ruska pedagogija, njene glavne ideje, trendovi i ličnosti] (2nd ed.). Ст. Петербург: СПБ.

Колесов, А. Е., \& Хрипкова, А. Г. (1982). Мальчик - подросток - юноша: Пособие для учителей [Dječak - tinejdžer - mladić: Priručnik za učitelje]. Москва: Просвещение.

Кузнецова, И. (1998). »Школы здоровья« в зоне российского Чернобыля [»Škole zdavlja« u zoni ruskog Černobila]. Народное образование, 9-10, 229-230.
Аазурский, А. Ф. (1913). Школьные характеристики [Školske karakteristiuke] (2nd ed.). Ст. Петербург: СПБ.

Аесгафт, П. Е. (1898). Значение физического образования в семье и школе [Značaj fizičkog vaspitanja u porodici i školi]. Русккая школа, 9, 75-91.

Аях, В. И., Кофман, А. В. и Мейксон, Г. В. (1996). Комплексная программа физического воспитания учашихся [Sveobuhvatni program fizičkog vaspitanja učenika]. Москва: [n.p.].

Мимьман, И. И. (1940). Беседы по охране здоровья в III кл. начальной школь [Razgovori o zdravlju u III reazredu osnovne škole]. Москва: Ин-та сан. просв. НКЗАрава СССР.

Мильман, И. И. (1966). Гигиеническое воспитание и обучение в начальной школе [Zdravstveno vaspitanje u osnovnoj školi]. Москва: [n.p.].

Ministarstvo obrazovanja. (1920). Положение о метней школе [Pravila o ljetnoj školi]. Moskva.

Нечаев, А. П. (1899). Об умственном утомлении [O mentalnom zamoru]. Русккий начальныцй учитель, 1.

Нимен, А. Б. (1941). Опыт санитарнопросветительской работы в 113 школе Советского района г. Москвы [Iskustvo u zdravstvenom vaspitanju u 113 školi Sovjetskog Distrikta Moskva]. Начальная школа, 8.

Нимен, А. Б. (1945). Воспитание гигиенических навыков в начальной школе [Higijensko obrazovanje u osnovnim školama]. Начальная школа, 6.

Покровский, Е. А. (1983). Аетские игры и гимнастика в отношении воспитания и здоровья молодежи [Dječije igre i vježbe za obuku i zdravlje mladih]. Москва: [n.p.].

Положение о еАиной трудовой школе [Pravilnik о zajedničkom radu škole]. (1918). Москва: [n.p.].

Равкин, 3. И. (1988). Очерки истории школьг и педагогической мысли народов СССР (1941-1961) [Eseji o istoriji škole i pedagoške misli naroda SSSR (1941-1961)]. Москва: Педагогика.

Рубинштейн, М. М. (1920). Очерки педагогической психологии в связи с общей педагогикой [Eseji о psihološkoj pedagogiji u vezi sa opštom pedagogijom] (4th ed.). Москва: [n.p.].

Семашко, Н. А. (1947). Очерки по теории организачии здравоохранения [Eseji o teoriji javnih usluga zdravstvene organizacije]. [s.l.]: [n.p.].

Шарипова, А. А. (1990) Научные основъг гигиенического воспитания школьников [Naučne osnove higijenskog vapsitanja učenika]. (Upblis- 
hed doctoral disertation). University of Tashkent.

Совјетов, В. Г. (1956). Охрана здоровья детей и подростков во время Вемикой

Отечественной войны [Zaštita zdravlja djece i tinejdžera tokom Velikog otadžbinskog rata].

Гигиена и санитария, 5-6, 45-48.
Цейтлин, А. Г. (1963). Физическое развитие детей и подростков [Fizički razvoj djece i adolescenata]. Москва: Медгиз.

Выготский, А. С. (1931). Развитие высиих психических функиий [Razvoj viših mentalnih funkcija]. Москва: [n.p.].

Primljeno: 19 jula 2011. godine Izmjene primljene: 18. novembar 2011. godine Odobreno: 10. decembra, 2011. godine

Correspodence to: Prof. Vladimir Irhin, PhD 308015, г. Белгород, ул. Чапаева, А.13, кВ. 61 Rusija e-mail: irhin@bsu.edu.ru Phone: 8-4722-220-310 